\title{
Diluwang Ponorogo Narrative as Enrichment of Materials in Historical Learning Based on Local Wisdom
}

\author{
Itama Citra Dewi Kurnia Wahyu, Warto, Leo Agung S \\ Universitas Sebelas Maret \\ citraitama@student.uns.ac.id
}

Article History

accepted 1/09/2020

approved 4/10/2020

published 1/12/2020

\begin{abstract}
History learning generally refers to the material in the textbook and does not mention the local history that is around students. As a result, students are less interested and do not understand the historical material presented by the teacher. Lack of knowledge about local history in history learning material has an impact on the fading of the local values of students. The purpose of this study was to identify the use of Dluwang Ponorogo narrative as material enrichment in local wisdom-based historical learning. The method used in this research is qualitative research with data collection techniques in the form of literature studies. The findings of this study resulted in the conclusion that the use of local history in enriching history learning materials can increase the locality of learners. The enrichment of material in historical learning based on local wisdom can be obtained by students by studying the local history of the area where they live. In fact, local history is shaped by the local wisdom of the community and local wisdom itself comes from the culture of a community.
\end{abstract}

Keywords : Dluwang ponorogo, material enrichment, historical learning, local wisdom

\begin{abstract}
Abstrak
Pembelajaran sejarah pada umumnya mengacu pada materi yang ada pada buku teks dan kurang menyinggung tentang sejarah lokal yang ada disekitar peserta didik. Akibatnya peserta didik kurang tertarik dan tidak memahami materi sejarah yang disampaikan oleh guru. Kurangnya pengetahuan tentang sejarah lokal pada materi pembelajaran sejarah berimbas pada lunturnya nilai-nilai lokalitas peserta didik. Tujuan penelitian ini adalah untuk mengidentifikasi penggunaan Narasi Dluwang Ponorogo sebagai pengayaan materi dalam pembelajaran sejarah berbasis kearifan lokal. Metode yang digunakan dalam penelitian ini adalah kualitatif research dengan teknik pengumpulan data berupa studi pustaka. Temuan penelitian ini menghasilkan kesimpulan bahwa penggunaan sejarah lokal dalam pengayaan materi pembelajaran sejarah dapat meningkatkan lokalitas peserta didik. Pengayaan materi dalam pembelajaran sejarah berbasis kearifan lokal dapat diperoleh peserta didik dengan mempelajari sejarah lokal daerah tempat tinggal. Sejatinya sejarah lokal dibentuk oleh kearifan lokal masyarakat dan kearifan lokal sendiri bersumber dari kebudayaan suatu masyarakat.
\end{abstract}

Kata Kunci: Dluwang ponorogo, pengayaan materi, pembelajaran sejarah, kearifan lokal

Social, Humanities, and Education Studies (SHEs): Conference Series https://jurnal.uns.ac.id/shes

p-ISSN 2620-9284

e-ISSN 2620-9292

This work is licensed under a Creative Commons Attribution-ShareAlike 4.0 International License. 


\section{PENDAHULUAN}

Kemajuan zaman dan pesatnya perkembangan teknologi merupakan dua sisi yang tidak dapat dipisahkan dari kehidupan manusia. Manusia sebagai pencipta sekaligus konsumen dari teknologi terus melakukan pembaharuan dalam bidang IPTEK (IImu Pengetahuan dan Teknologi) guna mempermudah aktivitas manusia. Salah satu perkembangan teknologi yang dapat dirasakan adalah penggunaan alat komunikasi berupa handphone atau smart phone. Setiap tahunnya produsen smart phone melakukan upgrade terhadap produknya agar tetap laku di masyarakat. Hal tersebut membuktikan bahwa teknologi sangat berpengaruh pada kemajuan zaman.

Pieterse menyatakan bahwa sejatinya globalisasi dibentuk oleh perubahan teknologi (Pieterse 2004, 9). Perubahan teknologi yang ada mengakibatkan munculnya suatu masa yang dikenal dengan istilah globalisasi atau modernitas. Sehingga dapat dikatakan bahwa perubahan teknologi dan globalisasi saling berhubungan. Di mana suatu negara yang tingkat teknologinya maju dapat dipastikan bahwa masyarakatnya tersebut hidup di zaman modern.

Intepretasi yang paling umum dari globalisasi adalah gagasan bahwa dunia menjadi lebih seragam dan terstandarisasi melaui sinkronisasi teknologi, komersial, dan budaya yang berasal dari barat (Pieterse 2004, 59). Albrow dalam Pieterse menyatakan bahwa globalisasi mengacu pada semua proses di mana orang-orang dimasukkan ke dalam satu masyarakat dunia atau masyarakat global. Secara sederhana globalisasi membawa manusia pada westernization atau pembaratan, di mana masyarakat digiring untuk menggunakan teknologi maupun budaya barat. Secara tidak langsung manusia telah mengaplikasikan budaya barat ke dalam kehidupannya sehari-hari.

Penggunaan teknologi dan budaya barat di era modern secara kasat mata banyak memberikan manfaat bagi kehidupan manusia. Salah satunya adalah semakin mudah dan cepatnya manusia dalam melakukan aktivitas. Namun di sisi lain, penggunaan teknologi dan budaya barat membawa dampak negatif bagi masyarakat, khususnya bagi generasi muda. Dampak negatif tersebut dapat dilihat dari gaya hidup generasi muda yang mengacu pada budaya global, seperti pakaian, pergaulan dan sebagainya. Agus Mulyana (Mulyana 2017) menyatakan bahwa tertanamnya pandangan global pada individu-individu dapat berdampak pada tercerabutnya nilai-nilai lokalitas yang dimiliki generasi muda. Gaya hidup barat yang diadopsi oleh generasi muda dapat menimbulkan anggapan bahwa hal-hal yang bersifat tradisional adalah terbelakang.

Pendidikan memegang peranan penting dalam meningkatkan kapasitas pembelajaran (Joyce dan dkk 2009, 1). Peningkatan tersebut dapat dilihat melalui perkembangan proses belajar mengajar di kelas. Sejatinya pembelajaran diartikan sebagai proses kerja sama antara guru dan peserta didik dalam memanfaatkan segala potensi dan sumber yang ada, baik potensi yang berasal dari dalam diri maupun potensi yang ada diluar peserta didik. Potensi dalam diri peserta didik terdiri atas minat, bakat, dan kemampuan dasar yang dimiliki, sedangkan potensi dari luar terdiri atas lingkungan, sarana, dan sumber belajar. Sehingga dapat dikatakan agar pembelajaran dapat berlangsung dengan baik maka pembelajaran bukan hanya terfokus pada guru atau peserta didik tetapi guru dan peserta didik secara bersama-sama berusaha mencapai tujuan pembelajaran yang telah ditentukan.

Pendidikan menjadi salah satu tameng yang dapat digunakan generasi muda dalam menyikapi globalisasi di era modern saat ini. Sejatinya pendidikan merupakan aspek fundamental bagi kehidupan bangsa (Agung 2011, 392). Melalui pendidikan generasi muda dapat belajar dan menemukan jati diri mereka sebagai generasi penerus bangsa. Sejalan dengan Leo Agung, Jean Piaget menyatakan bahwa pendidikan sebagai penghubung dua sisi, disatu sisi individu sedang tumbuh dan disisi lain nilai sosial, intelektual, dan moral yang menjadi tanggung jawab pendidik untuk mendorong peserta didik (Sagala 2013, 1). Secara sederhana pendidikan menuntut sebuah nilai, di 
mana nilai yang dimaksud adalah norma yang berfungsi sebagai penunjuk dalam mengidentifikasi apa yang diwajibkan, diperbolehkan, dan dilarang.

Salah satu mata pelajaran yang memiliki peranan penting dalam pembentukan moral, sikap serta jati diri generasi muda adalah pelajaran sejarah. Sejarah merupakan mata pelajaran yang menanamkan pengetahuan, sikap, dan nilai-nilai mengenai proses perubahan dan perkembangan masyarakat Indonesia dan dunia dari masa lampau hingga kini (Agung dan Wahyuni 2013, 55). Melalui pengajaran sejarah, peserta didik mampu mengembangkan kopetensi untuk berpikir secara kronologis dan memiliki pengetahuan tentang masa lampau yang dapat digunakan untuk memahami proses berkembang serta perubahan yang terjadi dalam masyarakat. Melaui pengajaran sejarah pula peserta didik dapat memahami adanya keragaman sosial budaya dalam masyarakat yang dapat digunakan untuk menemukan dan menumbuhkan jati diri peserta didik ditengah-tengah masyarakat dunia. Selain itu, dengan mempelajari sejarah peserta didik akan didorong untuk dapat berpikir kritis-analisis dalam memahami kehidupan masa kini dan masa yang akan datang.

Pada umumnya mata pelajaran sejarah merupakan bidang studi yang kurang diminati peserta didik. Bahkan dianggap sebagai bidang studi yang kurang penting atau second subject. Widja (Agung dan Wahyuni 2013, 64) menegaskan bahwa pengajaran sejarah di sekolah sering memunculkan kesan tidak menarik, bahkan cenderung membosankan sebab guru sejarah hanya memberikan fakta-fakta berupa urutan tahun dan peristiwa belaka. Sedangkan bagi para peserta didik, selama mempelajari sejarah mulai dari jenjang sekolah dasar hingga sekolah menengah atas mereka hanya mengulang materi yang sama pada setiap jenjangnya. Selain itu, pembelajaran sejarah pada umumnya mengacu pada materi yang ada pada buku teks. Sehingga kesan sebagai bidang studi hafalan melekat pada pelajaran sejarah.

Selain fakta umum di atas, mata pelajaran sejarah yang disampaikan pada jenjang sekolah kurang menyinggung tentang sejarah lokal yang ada di sekitar peserta didik. Akibatnya peserta didik kurang tertarik dan cenderung tidak memahami materi yang disampiakan oleh guru. Penggunaan materi sejarah lokal yang ada di sekitar daerah peserta didik secara psikologi dapat meningkatkan minat peserta didik, karena secara tidak langsung peserta didik memiliki ikatan emosional dengan daerah tempat tinggalnya. Dampak yang ditimbulkan dari kurangnya pengetahuan peserta didik tentang sejarah lokal pada materi pembelajaran sejarah berimbas pada lunturnya nilai-nilai lokalitas peserta didik. Hal tersebut dikarenakan terdapat nilai-nilai kearifan lokal yang terkandung dari sejarah lokal itu sendiri, melalui sejarah lokal peserta didik dapat mempelajari bagaimana masyarakat atau nenek moyangnya menjalani hidup dimaa lalu dan nilai-nilai apa yang ada pada sejarah lokal.

Penggunaaan Narasi Dluwang Ponorogo sebagai pengayaan materi dalam pembelajaran sejarah kiranya dapat dijadikan sebagai salah satu alternatif dalam pembelajaran sejarah, khususnya pembelajaran sejarah pada jenjang sekolah menengah atas di Ponorogo. Pemilihan materi Narasi Dluwang Ponorogo sebagai pengayaan materi dalam pembelajaran sejarah tidak lepas dari warisan sejarah lokal yang dimiliki masyarakat Ponorogo. Dluwang Ponorogo merupakan salah salah satu warisan budaya masyarakat Ponorogo yang tidak banyak diketahui oleh masyarakat Ponorogo, khususnya oleh generasi muda. Dengan menggunakan Narasi Dluwang Ponororgo sebagai pengayaan materi pembelajaran sejarah diharapkan masyarakat Ponorogo khususnya generasi muda dapat lebih mengenal sejarah lokal daerahnya dan mengambil kearifan lokal yang dimiliki nenek moyangnya. Melaui pembelajaran sejarah yang berbasis pada kearifan lokal diharapkan generasi muda lebih sadar dan tertarik untuk belajar sejarah. Melihat dari permasalahan yang ada maka pertanyaan penelitian yang diajukan pada kajian ini adalah:

1. Bagaimana penggunaan Narasi Dluwang Ponorogo dalam pembelajaran sejarah? 
2. Bagaimana pemahaman Narasi Dluwang Ponorogo sebagai pengayaan materi dalam pembelajaran sejarah berbasis kearifan lokal?

\section{METODE}

Penelitian ini mengkaji tentang penggunaan Narasi Dluwang Ponorogo sebagai pengayaan materi dalam pembelajaran sejarah berbasis kearifan lokal. Pembelajaran sejarah sendiri diberikan pada jenjang sekolah menengah atas (SMA). Secara khusus untuk bidang studi Sejarah dalam Kurikulum 2013 di SMA dibedakan menjadi dua, yaitu mata pelajaran Sejarah Indonesia yang sifatnya wajib bagi setiap jenjang untuk semua peminatan dan pelajaran Sejarah untuk peminatan IPS (Kurniawan 2018, 10). Mata pelajaran Sejarah Indonesia memfokuskan pada penguatan pendidikan karakter, sedangkan untuk pelajaran Sejarah Peminatan lebih bersifat akademis untuk menguasai ilmu seacara akademis.

Pembelajaran sejarah berbasis kearifan lokal dengan memanfaatkan sejarah lokal sekitar daerah peserta didik dinilai sebagai salah satu terobosan guna mendekatkan peserta didik pada materi sejarah. Sehingga materi sejarah yang diajarkan tidak terbatas pada materi yang ada di buku paket, tetapi peserta didik secara tidak langsung dapat belajar tentang kaerifan lokal yang dimiliki oleh nenek moyangnya dan mengenal warisan budaya yang dimiliki daerahnya. Mempelajari sejarah lokal daerah juga akan meningkatkan rasa bangga dan menghargai budaya yang dimiliki bangsanya.

Metode yang digunakan dalam penelitian ini adalah metode kualitatif research dengan teknik pengumpulan data berupa studi pustaka. Kualitatif reasearch adalah meetode-metode untuk mengeksplorasi dan memahami makna yang- oleh sejumlah individu atau sekelompok orang dianggap berasal dari masalah sosial atau kemanusiaan (Creswell 2016, 4). Sedangkan teknik pengumpulan data berupa studi pustaka dilakukan oleh peneliti dengan mengumpulkan sejumlah buku-buku, jurnal, artikel dan sumber tertulis lainnya yang berhubungan dengan masalah dan tujuan penelitian. Riset pustaka memanfaatkan sumber perpustakaan untuk memperoleh data penelitiannya. Tegasnya riset pustaka membatasi kegiatan hanya pada bahan-bahan koleksi perpustakaan tanpa memerlukan riset lapangan (Zed 2008, 2). Idealnya suatu penelitian hendaknya menggunakan gabungan antara riset pustaka dan riset lapangan, namun dengan adanya kondisi pandemi saat ini peneliti akhirnya menggunakan studi pustaka sebagai metode penelitian.

\section{Narasi Dluwang Ponorogo}

\section{HASIL DAN PEMBAHASAN}

Budaya tulis di Indonesia telah dimulai pada abad ke-5, di mana budaya tulis tersebut belum menggunakan kertas sebagai media tulisnya. Pada masa itu media tulis yang digunakan adalah batu dan logam atau saat ini kita mengenalnya dengan nama prasasti. Selain itu, media tulis yang digunakan masyarakat Indonesia sebelum menggunakan media kertas adalah daun lontar (Soekmono 1981, 104-105). Namun naskah-naskah yang ditulis di atas daun lontar tidak dapat bertahan lama terutama pada masa Islam. Beberapa naskah yang ditulis di atas daun lontar (kropak) saat ini masih dapat kita jumpai di wilayah Bali keturunan Hindu Majapahit.

Indonesia sendiri memiliki peninggalan-peninggalan tulisan masa lampau dalam jumlah besar, yaitu tidak kurang dari 5000 naskah dengan 800 teks tersimpan dalam museeum dan perpustakaan di beberapa negeri (Baried, et al. 1994, 9). Berdasarkan data tersebut maka tidak mengherankan banyak ditemukan peninggalan tertulis berupa naskah di Indonesia. Naskah adalah semua jenis peninggalan tertulis pada bidang kertas, daluwang, kulit kayu, lontar, kulit binatang dan lainnya (Masyudi 2012, 101). Istilah lain untuk menyebut naskah ialah istilah manuscript dari bahasa Inggris, handschrift (Belanda), dan manuscrit (Prancis). Pada umumnya di Indonesia arti kata 
naskah bermacam-macam. Hal tersebut dikarenakan kata naskah selalu diiringi dengan kata-kata lainnya seperti naskah pidato, naskah undang-undang, naskah perjanjian, dan lainnya. Sehingga kata naskah telah bergeser pada arti teks.

Membahas tentang naskah tidak dapat dilepaskan dari sejarah kertas, di mana banyak naskah-naskah yang ditemukan di Indonesia ditulis di atas kertas. Terdapat dua jenis kertas yang ada di Indonesia, yaitu kertas tradisonal dan kertas pabrik (Dienaputra $2005,5)$. Kertas pabrik dapat dipahami sebagai kertas yang umum digunakan saat ini. Sedangkan kertas tradisional adalah kertas hasil kreasi bangsa Indonesia yang dibuat melalui cara-cara tradisional dengan bahan mentah yang pada umumnya dibuat dari kulit kayu. Terdapat beberapa kertas tradisional yang digunakan sebagai alas tulis di Indonesia, seperti pustaha (Batak), kertas dluang/ daluwang, dhalubang (Madura) dan lainnya.

Salah satu kertas tradisional yang pernah di produksi dan dikembangkan oleh orang Jawa adalah dluwang Ponorogo atau paper of Java (Guillot 1983, 105). Dluwang merupakan istilah kertas dalam bahasa Jawa kasar (ngoko), sedangkan dalam bahasa halus (kromo) kertas disebut dengan istilah dlancang. Orang Eropa menyebut dluwang sebagai paper of Java atau kertas kulit kayu. Namun bagi kaum kolonial istilah dluwang disebut dengan istilah Javanese paper (Teygeler 1996). Istilah dluwang Ponorogo mengacu pada tempat pusat pembuatan utama kertas tersebut yaitu di Ponorogo.

Ponorogo adalah salah satu kabupaten yang ada di wilayah Jawa Timur. Secara administratif Ponorogo masuk wilayah Provinsi Jawa Timur yang terletak pada $111^{\circ} 7^{\prime}$ hingga $111^{\circ} 57^{\prime}$ BT dan $7^{\circ} 49^{\prime}$ hingga $8^{\circ} 20^{\prime}$ LS (BPPD Kabupaten Ponorogo 2013, 1). Wilayah Ponorogo berbatasan dengan Kabupaten Madiun, Kabupaten Magetan dan Kabupaten Nganjuk di sebelah utara. Di sebelah timur berbatasan dengan Kabupaten Tulungagung dan Kabupaten Trenggalek, sedangkan di sebelah Selatan berbatasan langsung dengan Kabupaten Pacitan serta di sebelah barat berbatasan dengan Kabupaten Pacitan dan Kabupaten Wonogiri.

Sekitar abad ke-18 Ponorogo yang pada masa itu termasuk daerah Mancanegara Wetan sedang giat-giatnya dalam memproduksi kertas untuk kepentingan pesantren. Karena kebutuhan dluwang pada saat itu meningkatan maka masyarakat Tegalsari memproduksi dluwang dalam jumlah besar (Nurdianto, Joebagio dan Djono 2018, 198). Kebutuhan dluwang meningkat dikarenakan kertas Cina yang berbahan bambu tidak banyak diminati masyarakat Jawa pada masa itu.

Salmon (1983) menyatakan bahwa kertas buatan Jawa tebal dan tahan lama (Reid 2014, 267). Sedangkan Teygeler mengklasifikasikan kualitas dluwang yang dihasilkan di Jawa Timur ke dalam tiga klasifikasi, yaitu kualitas terbaik digunakan untuk naskah dan surat; kualitas menengah digunakan untuk kertas tulis, buku sederhana, wayang beber dan bahan penjilid buku; sedangkan kualitas kasar digunakan untuk kertas pembungkus, layang-layang dan map (Teygeler 1996). Kualifikasi terhadap dluwang tersebut membuktikan bahwa kualitas dluwang Jawatimur khususnya dluwang Ponorogo tergolong unggul dari kertas lainnya.

Tegalsari merupakan desa tempat memproduksi dluwang Ponorogo. Tegalsari merupakan desa perdikan yang masuk wilayah Kecamatan Jetis (Purwowijoyo 1984). Tegalsari merupakan salah satu desa istimewa yang ada di kota Ponorogo karena terdapat pondok pesantren yang dikenal dengan nama Pondok Pesantren Tegalsari. Pesantren Tegalsari adalah salah satu pesantren tertua di Indonesia yang didirikan oleh Kiai Ageng Mohamad Besari pada awal abad ke-18. Selain itu, pada tahun 1742 Paku Buwono II pernah mengungsi ke Ponorogo dan singgah di desa Tegasari.

Dluwang Ponorogo memiliki ciri bertekstur kasar, berwarna merah, kuat, tahan, tapi seratnya agak tidak rata (Reid 2014, 268). Dluwang Ponorogo dibuat menggunakan bahan mentah berupa serat-serat pohon murbei atau glugu (Broussonetia papyrifera). Serat-serat tersebut selanjutnya direndam dan dipukul-pukul di atas landasan rata. Guillot (1983) menyatakan bahwa sebenarnya dalam sumber-sumber sejarah Jawa 
sejak abad ke-9 telah diterapkan cara pembuatan kertas tersebut namun lebih dijadikan sebagai sejenis pakaian untuk pertapa. Selain itu, orang Jawa sebenarnya telah meniru cara membuat kerta dari Cina, namun mereka tidak menggunakannya untuk menulis tetapi lebih kepada bahan untuk pakaian, pembungkus, wadah lukisan.

Proses pembuatan Dluwang Ponorogo secara rinci dijelaskan oleh Guillot dalam Le dluwang ou (papier javanais). Proses pertama adalah dengan memotong batang pohon murbei atau glugu yang telah berusia sekitar dua tahun. Kemudia batang dikupas sampai gubal menggunakan alat. Bagian luar selanjutnya di rendam dalam air beberapa jam hingga beberapa hari. Kulit glugu dipisahkan dari batangnya dan dipotong-potong dengan panjang yang sama sesuai dengan ukuran yang diinginkan dan selanjutnya direndam kembali. Pada tahap selanjutnya dengan bantuan alat seperti palu tembaga, kulit glugu yang sudah direndam dipukul-pukul hingga mendapat ukuran atau ketebalan yang diinginkan. Selanjutnya kertas dibiarkan untuk berfermentasi dan pada tahap akhir kertas dipoles.

Sebagai media tulis Dluwang Ponorogo dibandingkan dengan media tulis lainnya dinilai lebih jelas. Raffles telah mencatat bahwa proses pembuatan dluwang mirip (sangat mirip dengan yang digunakan oleh populasi Kepulauan Laut Selatan). Dalam penelitian Guillot yang dilakukan di Tegalsari, ia memperoleh informasi bahwa masyarakat Tegalsari telah menggunakan bahan-bahan mentah seperti pohon nangka untuk membuat kertas dan pohon mlinjo untuk kertas kaso dan Hazeu. Berdasarkan temuan Guillot dapat dikatakan bahwa local genius yang dimiliki masyarakat Tegalsari telah menunjukkan kemandirian dalam bidang produksi kertas.

\section{Pembelajaran Sejarah berbasis Kearifan Lokal}

Pembelajaran sejarah pada jenjang sekolah menengah atas banyak mengalami beberapa masalah. Mulai dari kurangnya minat peserta didik, kesan pelajaran sejarah yang cenderung mata pelajaran hapalan, bahkan sejarah dianggap sebagai second subject setelah mata pelajaran eksakta. Kesan mengulang materi yang sama pada setiap tingakatan pendidikan membuat sejarah semakin membosankan. Peserta didik akan cenderung belajar sejarah hanya ketika akan menghadapi ulangan karena guru seringkali memberikan soal tentang hapalan. Surachmad menyatakan bahwa seringkali pelajaran sejarah tidak membawa peserta didik pada kemampuan menganalisis peristiwa dunia dan negaranya secara historis (Agung dan Wahyuni 2013, 64). Akibatnya kemampuan peserta didik untuk berpikir kritis dan historis menjadi terhenti dan tidak terasah.

Pada implementasi kurikulum 2013 pembelajaran telah mengintegrasikan empat hal penting yakni Penguatan Pendidikan Karakter (PPK), keterampilan literasi, kompetensi pembelajaran abad 21 (communication, collaboration, critical thinking and problem solving) dan HOTS (Higher Order Thinking Skill) (Kurniawan 2018, 10). Dengan adanya integrasi keempat hal tersebut diharapkan peserta didik dapat siap untuk terjun ke tengah masyarakat global apabila telah menyelesaikan pendidikan. Pada kurikulum 2013 bidang studi sejarah jenjang SMA dibedakan menjadi dua, yaitu Sejarah Indonesia dan Sejarah Peminatan. Untuk Sejarah Indonesia bersifat wajib untuk setiap jenjang dan semua peminatan. Mata Pelajaran Sejarah Peminatan hanya diwajibkan bagi peminatan IPS. Kedua bidang studi Sejarah tersebut dibedakan berdasarkan fokus tujuan pembelajaran yang diharapkan. Mata Pelajaran Sejarah Indonesia lebih memfokuskan pada upaya penguatan pendidikan karakter sehingga setiap lulusan mempu meiliki kesadaran sejarah yang tinggi serta nilai-nilai kebangsaan yang tinggi pula. Untuk Sejarah peminatan lebih bersifat akademis, sehingga dapat dihasilkan bibit-bibit penekun dan pengembang ilmu sejarah.

Meskipun implementasi pembelajaran sejarah dengan menggunakan kurikulum 2013 telah diatur sedemikian rupa, namun penerapan di lapangan tetap banyak mengalami kendala. Kendala utama yang dimiliki pembelajaran sejarah adalah materi 
yang disampaikan oleh guru terlalu fokus pada materi yang ada di dalam buku. Guru kurang mengeksplor materi sejarah yang berkaitan dengan lingkungan sekitar tempat tinggal peserta didik. Padahal dengan memasukkan materi tentang sejarah lokal sekitar tempat tinggal maka secara psikologis peserta didik akan tertarik. Hal tersebut dikarenakan peserta didik secara tidak langsung memiliki ikatan emosinal dengan daerahnya.

Sebagai upaya untuk mengatasi lunturnya nilai-nilai lokalitas peserta didik maka perlu adanya pembelajaran sejarah berbasis kearifan lokal. Istilah kearifan lokal muncul sebagai suatu pandangan hidup ketika orang memiliki pandangan terhadap arus besar (Mulyana 2017). Arus besar yang dimaksud adalah pandangan-pandangan global yang tercipta akibat globalisasi. Kearifan lokal menurut arti bahasa adalah kearifan setempat (local wisdom) yaitu gagasan-gagasan lokal yang bersifat bijaksana, penuh kearifan, memiliki nilai yang tertanam dan diikuti oleh masyarakat. Dalam perspektif sejarah, kearifan lokal termasuk bagian dari kesadaran sejarah.

Kearifan lokal bersumber pada kebudayaan masyarakat dalam lokalitas tertentu. Kearifan lokal yang ada pada suatu lokalitas pada akhirnya akan membentuk sejarah lokal. Hal tersebut dikarenakan kajian sejarah lokal adalah studi tentang kehidupan masyarakat atau khususnya komunitas dari suatu lingkungan sekitar (neighborhood) tertentu dalam berbagai aspek kehidupan manusia (Widja 1991, 15). Sehingga dengan mempelajari sejarah lokal sekitar peserta didik maka tingkat lokalitas peserta didik akan meningkat dan lebih mencintai daerahnya.

Pembelajaran sejarah berbasis kearifan lokal dengan mengambil tema sejarah lokal berupa Narasi Dluwang Ponorogo sebagai pengayaan materi dapat menjadi terobosan untuk guru di wilayah Ponorogo. Alasan pemilihan dluwang Ponorogo adalah karena banyak generasi muda yang tidak mengetahui apa yang dimaksud dengan dluwang. Selain itu, dluwang Ponorogo merupakan bukti nyata bahwa dimasa lalu masyarakat Ponorogo telah memiliki kebudayaan maju khususnya dalam bidang literasi. Hal tersebut menunjukkan bagaimana kemandirian masyarakat Ponorogo saat itu dalam bidang literasi. Banyak nilai kearifan lokal yang dapat diperoleh peserta didik dengan mempelajari materi tersebut yaitu kemandirian, kerjakeras, mencintai produk lokal, dan masih banyak lainnya.

\section{KESIMPULAN}

Kemajuan zaman dan teknologi membawa banyak perubahan bagi kehidupan manusia. Perubahan tersebut dapat dilihat dari sisi positif berupa semakin mudah dan cepatnya aktivitas manusia. Sedangkan dari sisi negatifnya adalah dengan adanya kemajuan zaman khususnya teknologi maka nilai-nilai lokalitas pada generasi muda mulai pudar. Generasi muda mulai lupa dengan kebudayaan lokal dan lebih menyukai gaya hidup global seperti pakaian, pergaulan dan cara pandang budaya barat. Gaya hidup barat yang diadopsi oleh generasi muda dapat menimbulkan anggapan bahwa hal-hal yang bersifat tradisional adalah terbelakang.

Sebagai upaya untuk meminimalisir lunturnya nilai-nilai lokalitas generasi muda maka diperlukan adanya pengetahuan tentang sejarah lokal pada materi pembelajaran sejarah di sekolah. Materi pembelajaran sejarah di sekolah yang hanya terfokus pada materi nasional akan membuat peserta didik bosan dan cenderung tidak menyukai pelajaran sejarah. Dengan memasukkan materi sejarah lokal sekitar tempat tinggal peserta didik maka secara psikologis akan tercipta ketertarikan karena peserta didik lebih memahami dan memiliki ikatan emosinal dengan daerah tempat tinggalnya.

Pembelajaran sejarah berbasis kearifan lokal menjadi salah satu akternatif untuk meningkatkan nilai-nilai lokalitas peserta didik. Narasi dluwang Ponorogo sebagai pengayaan materi akan membuat peserta didik menyadari bahwa msyarakat Ponorogo dimasa lalu telah maju dalam hal budaya dan literasi. Peserta didik secara tidak 
langsung akan merasa bangga dan lebih mencintai daerahnya. Sejatinya sejarah lokal dibentuk oleh kearifan lokal masyarakat dan kearifan lokal sendiri bersumber dari kebudayaan suatu masyarakat. Sehingga dengan mempelajari sejarah lokal maka peserta didik akan dapat mengambil nilai-nilai kearifan lokal yang dimiliki oleh daerahnya.

\section{DAFTAR PUSTAKA}

Agung, Leo. 2011. "Character Education Integration in Social Studies Learning." International Jornal of History Education 392-403.

Agung, Leo, dan Sri Wahyuni. 2013. Perencanaan Pembelajaran Sejarah. Yogyakarta: Ombak.

Baried, Siti Baroroh, Sulastin Sutrisno, Siti Chamamah Soeratno, Sawu, dan Kun Zachrun Istanti. 1994. Pengantar Teori Filologi. Yogyakarta: Badan Penelitian dan Publikasi Fakultas (BPPF) Seksi Filologi Fakultas Sastra UGM.

BPPD Kabupaten Ponorogo. 2013. Ponorogo dalam Angka Ponorogo in Figures. Ponorogo: BPPD Kab. Ponorogo.

Creswell, John W. 2016. Research Desain Pendekatan Metode Kualitatif, Kuantitatif, dan Campuran. Yogyakarta: Pustaka Pelajar.

Dienaputra, Reiza D. 2005. "Sejarah Kertas Indonesia." Jurnal Legenda Kertas Menelusuri Jalan Sebuah Peradaban 1-17.

Guillot, Claude. 1983. "Le Dluwang ou (papier javanais." In Archipel Vol. 26 105-116.

Joyce, Bruce, dan dkk. 2009. Models of Teaching. Yogyakarta: Pustaka Pelajar.

Kurniawan, Hendra. 2018. Literasi dalam Pembelajaran Sejarah. Yogyakarta: Gava Media.

Masyudi. 2012. "Temuan Naskah-Naskah Kuno di Masjid Layur Semarang, Jawa Tengah.” Jurnal Berkala Arkeologi Vol. 32 No. 1101-110.

Mulyana, Agus. 2017. Mengembangkan Kearifan Lokal dalam Pembelajaran Sejarah. 1 Maret. Diakses September 2020. www.sejarah.upi.edu/artikel/dosen/mengembangkan-kearifan-lokal-dalampembelajaran-sejarah/.com.

Nurdianto, Saifuddin Alif, Hermanu Joebagio, dan Djono. 2018. "Kajian Poskolonial Gerakan Pemikiran dan Sikap Ulama Pesantren Tegalsari dalam Pusaran Konflik Multidimensional di Jawa (1742-1862)." Jurnal Theologia Vol. 29 No. 1189-214.

Pieterse, Jan Nederveen. 2004. Globalization and Culture Global Melange. United States of America: Rowman \& Littlefield Publishers, inc.

Purwowijoyo. 1984. Babad Ponorogo Jilid V. Ponorogo: Dinas Pariwisata dan Seni Budaya Pemerintah Kabupaten Ponorogo.

Reid, Anthony. 2014. Asia Tenggara dalam Kurun Niaga 1450-1680 Jilid 1: Tanah di Bawah Angin. Jakarta: Yayasan Pustaka Obor Indonesia.

Sagala, Syaiful. 2013. Konsep dan Makna Pembelajaran. Bandung: Alfabeta. 
Soekmono. 1981. Sejarah Kebudayaan Indonesia 2. Yogyakarta: Kanisius.

Teygeler, R. 1996. "Dluwang a near-paper from Indonesia." IPH Congress book Vol. 11 134-145.

Widja, I Gde. 1991. Sejarah Lokal suatu Perspektif dalam Pengajaran Sejarah. Bandung: Angkasa Bandung.

Zed, Mestika. 2008. Metode Penelitian Kepustakaan. Jakarta: Yayasan Obor. 